\section{H OBITUARIES}

\section{Prof. John Percival}

John Percival was born at Carperby in Wensleydale on April 3, 1863, and died on January 26, 1949, being survived by his widow and son.

$\mathrm{He}$ was educated locally, but later proceeded to Cambridge and graduated fam St. John's College in 1888 with honours in Part W I and II of the Natural Science Tripos. Eyonds ing his boyhood he was an ardent field maturist and, while still a student, publighed a "Wora of Wensleydale" which listed 653 specios nnal varieties, of which all but ten had been seen (A. himself.

In 1891 he was appointed junior demonstrator in the Chemical Laboratories of the University of Cambridge, and joined that small band of educational pioneers, led by A. D. Hall, who carried agricultural science into the rural areas. During three years he gave numerous courses of "Cambridge University Local Lectures" on botany and chemistry in relation to agriculture, and it was this intimate contact with Surrey and Suffolk farmers and experience in wedding science to agricultural practice that laid the pattern of his life-work.

When the Wye Agricultural College was founded in 1894, Percival was appointed professor of botany and concentrated his attention mainly on hops and cereals. He published several papers on the history, varietal development and diseases of the hop plant which laid the foundations on which E. S. Salmon was to build so brilliantly later. He assembled a living museum of cereals, described in his pamphlet "The Chief Species, Races, and Varieties of European Cereals", this being his first essay in a field which was to become the dominant passion of his life. In 1902 he published a short paper in which the causal relation of Stereum purpureum to silver leaf disease was first demonstrated, a problem later developed by F. T. Brooks. In his teaching at Wye, Percival felt acutely the lack of any text-book of his subject, and met this need by his "Agricultural Botany"; in the course of thirty-eight years this ran into eight editions and was translated into many languages. It is easy nowadays to criticize this volume; but, in its day, it was a pioneering effort in a new field, a field itself almost created by Percival, and the several editions have largely shaped the development of the subject in university and college teaching.

In 1902, Percival was appointed director of the Agricultural Department in what was then the University College, Reading, and in 1907 became professor of agriculture. For ten years he had to cover the whole field of agriculture, and his publications ranged over such diverse topics as weeds, mountain pines, manures and manuring, and the "Soils of Dorset" ; in 1907 he was one of the presidents of the Second National Conference of the Poultry Industry. In 1910 he published his researches on "Potato 'Wart' Disease", which gave the disease and the pathogen their modern names and laid the foundations of our knowledge of this problem. During this period he was also assembling and making an intensive study of the world's wheats, and building up in Reading a centre of agricultural education and research. In 1910 he published his "Agricultural Bacteriology", again a pioneering effort in a new and rapidly developing field which the book largely patterned.

In 1912 a chair of agricultural botany was established in the College and Percival became the first professor, holding this appointment until his retirement in 1932 : in 1926 the College had become the University of Reading. Percival was at last able to devote all his energies to his wheats. Earlier he had founded an Agricultural Botanic Garden containing a living museum of wheats, and he developed this until it comprised many thousands of named species, varieties and races of Aegilops and Triticum collected from all over the world. In 1921 this work came to splendid fruition in his monumental treatise, "The Wheat Plant", which at once gave him recognition as the foremost world authority : among his correspondence are letters from Vavilov and other specialists containing glowing tributes to "this classic work".

During the next ten years Percival devoted his attention to the cytological analysis of Aegilops $\times$ Triticum hybrids, on which he published severa] papers, and began the preparation of his book on "Wheat in Great Britain" which was published in 1934 , and appeared in a second edition a few months before his death. During his last years he was actively engaged in research on seed germination and seedling growth. In his old Department at Reading there remain his fine herbarium of British plants, his remarkable collection of seeds, a complete set of dried specimens of his wheats with his annotations, and the living museum of wheats and the Agricultural Botanic Garden which he founded.

John Percival was no ordinary man. His force of character, tireless enthusiasm and immense physical and mental energies enabled him to achieve a vast amount of enduring work. He was an accomplished linguist, a musician and artist of merit, an expert photographer, a scholar, and a lover of books, of which he possessed an astonishingly wide and intimate knowledge. He was an inspired teacher with an encyclopædic knowledge of agriculture and botany on which he could draw at will. He was equally at home with both student and farmer; but there was always about him a certain brusqueness and an aloofness from the common world which made him impatient of trivialities; nor did he suffer fools gladly. $\mathrm{He}$ was a splendid field naturalist, loving wild things and wild and lonely places, and it was this passion that, in his earlier years, took him to remote Scandinavia to dwell for months among the Lapps, and later compelled him to the Alps and the Pyrenees, to the Welsh mountains, and ever and again to his own beloved Yorkshire dales.

John Percival was an eminent scientist who, perhaps, received more recognition in other countries than in his own, and in his passing, agricultural science has lost a memorable figure.

\section{William B. BRIERleY}

\section{Dr. M. C. Rayner}

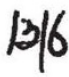

BY the sudden pleath of Dr. M. C. Rayner, on December $f r$, Bitish mycology has sustained a serious los for to the last moment she had been pursuing iff researches into the mycorrhizal habit in Slaxp, and, in fact, died only a few hours after visfing her experimental plots at Wareham Heath in Dorset. Relatively early in her career, Dr. Rayner had established herself as unquestionably the leading British authority on the subject of mycotrophy in plants-a position which she afterwards consolidated both by the volume of her own research, and by the breadth of her interests in her chosen field of work. 